\title{
Building innovation networks in science-based young firms: the selection of knowledge sources
}

\author{
Cristina Sousa* \\ DINÂMIA'CET-IUL, \\ Instituto Universitário de Lisboa (ISCTE-IUL), \\ Av. das Forças Armadas 1649-026 Lisboa, Portugal \\ E-mail: cristina.sousa@iscte.pt \\ *Corresponding author
}

\section{Margarida Fontes}

Laboratório Nacional de Energia e Geologia, Estrada do Paço do Lumiar, 22 - Edificio C, 1649-038 Lisboa, Portugal

and DINÂMIA'CET-IUL, Instituto Universitário de Lisboa (ISCTE-IUL), Av. das Forças Armadas 1649-026 Lisboa, Portugal E-mail: margarida.fontes@lneg.pt

\begin{abstract}
The paper investigates the strategic choices made by young science-based firms regarding the selection of knowledge sources. Data collected on Portuguese biotechnology firms are analysed with a view to answer to two research questions: whether, to what extent and in which conditions science-based entrepreneurs activate their social capital and/or build new knowledge relationships at start-up; whether and to what extent the knowledge relationships established at start-up persist and/or the firm builds relationships with new organisations. The results confirm the importance attributed to tie persistence but they also show that science-based firms need to search for new knowledge sources from the very early stages. Thus, their start-up behaviour departs from the one often depicted by the entrepreneurship literature, that emphasises the mobilisation of the entrepreneurs' social capital. Results also show that persistence of ties established at start-up is lower than would be expected.
\end{abstract}

Keywords: knowledge network; entrepreneurship; network building strategy; science-based firm.

Reference to this paper should be made as follows: Sousa, C. and Fontes, M. (2014) 'Building innovation networks in science-based young firms: the selection of knowledge sources', Int. J. Entrepreneurship and Small Business, Vol. 21, No. 3, pp.370-390.

Biographical notes: Cristina Sousa is a Research Fellow at DINÂMIACET/IUL and an Invited Assistant Professor at ISCTE/IUL. She received her Master's in Economics and Management of Science and Technology and her $\mathrm{PhD}$ in Economics, both from ISEG/UTL (Lisbon, Portugal). Her research interests include innovation, creation and circulation of knowledge 